\title{
Oncoplastic Thyroid Surgery Using A Bilateral Axillo-Breast Approach
}

\author{
Chan Yong Seong, M.D. ${ }^{1}$, Hyeong Won Yu, M.D. ${ }^{2}$, Young Jun Chai, M.D. ${ }^{3,4}$, Kyu Eun Lee, Ph.D. ${ }^{1,4}$ \\ Department of Surgery, 'Seoul National University Hospital and College of Medicine, Seoul, ${ }^{2}$ Seoul National University Bundang Hospital, Seongnam, ${ }^{3}$ Seoul \\ National University Boramae Medical Center, Seoul, ${ }^{4}$ Cancer Research Institute, Seoul National University College of Medicine, Seoul, Korea
}

Since the first use of the robot da Vinci system for thyroid surgery in 2007, robotic thyroidectomy (RT) via a bilateral axillo-breast approach (BABA) has become a popular surgical alternative for patients who wish to avoid scars on the neck. BABA RT provides excellent cosmetic satisfaction with surgical safety and oncologic completeness. Recently, the use of BABA RT has expanded beyond benign thyroid nodules and small-sized papillary thyroid carcinoma (PTC) to Graves' disease, relatively large PTCs, and PTC with lateral neck metastasis. Unfortunately, there are concerns about the use of this procedure for these additional indications. This review article summarizes postoperative outcomes of BABA RT for thyroid carcinoma, including quality of life, as well as expanding indications for BABA RT.

Keywords: Robotic surgical procedure, Thyroidectomy, Minimal invasive surgery, Laryngeal nerves

This is an Open Access article distributed under the terms of the Creative Commons Attribution Non-Commercial License (http:// creativecommons.org/licenses/by-nc/4.0/) which permits unrestricted non-commercial use, distribution, and reproduction in any medium, provided the original work is properly cited.
Received February 20, 2017

Revised March 28, 2017

Accepted April 6, 2017

Corresponding author

Kyu Eun Lee

Department of Surgery, Seoul

National University Hospital and

College of Medicine, 101 Daehak-ro,

Jongno-gu, Seoul 03080, Korea

Tel: $+82-2-2072-2081$

Fax: +82-2-766-3975

E-mail: kyueunlee@snu.ac.kr

Copyright $@ 2017$ The Journal of Minimally Invasive Surgery. All rights reserved.

\section{INTRODUCTION}

Thyroid carcinoma is the most common endocrine malignancy. ${ }^{1}$ Although conventional open thyroidectomy (OT) is safe and effective for patients with thyroid disease, it may result in undesired scars, including hyperemic, hypertrophic, crooked, and keloid scars. For many patients, especially women, surgical scarring after thyroid surgery is a major concern, as important as oncologic completeness. Various remote access surgical methods have been developed to avoid cosmetically undesirable scars, with bilateral axillo-breast approach (BABA) thyroid surgery being one of the most popular. ${ }^{2,3}$

In BABA as in OT, the patient is placed in the supine position with neck extension, followed by two circumareolar incisions (1.2 and $0.8 \mathrm{~cm}$ in size) and two $0.8 \mathrm{~cm}$-sized axillary incisions. The $1.2 \mathrm{~cm}$-sized incision is used for the camera port, and the three $0.8 \mathrm{~cm}^{-}$sized ports are used for the passage of surgical instruments. ${ }^{3}$ BABA provides the same view of both thyroid lobes as OT.

Originally, BABA techniques were developed for endoscopic thyroidectomy (ET). However, the learning curve of BABA for ET is steeper because the camera provides a 2-dimensional view and because this technique utilizes inflexible instruments that are difficult to manipulate. Beginning in 2007, with the development of the da Vinci robotic surgical system (Intuitive, Sunnyvale, CA, USA), ET began to be replaced by robotic surgery. The surgical robotic system was found to overcome the limitations of endoscopy by supplying a 3-dimensional magnified view, filtering out hand tremors, and providing fine motion scaling and multi-articulated hand-like motions. However, the role of the robot in thyroid surgery remains unclear, because conventional OT provides excellent outcomes 
and robotic thyroidectomy (RT) has disadvantages, including a longer operation time, higher costs, a higher degree of technical skill, and more advanced training than OT.

BABA RT is now called "oncoplastic thyroid surgery" because it can eliminate the thyroid lesion safely, both surgically and oncologically, as well as providing excellent cosmetic results. This review summarizes current knowledge on the comparative surgical outcomes of BABA RT and OT, as well as evaluating their effects on patient quality of life.

\section{SURGICAL SAFETY OF ONCOPLASTIC THYROID SURGERY}

\section{Recurrent laryngeal nerve injury}

The currently reported rates of transient and permanent recurrent laryngeal nerve (RLN) injury in patients undergoing BABA RT are shown in Table 1. Although transient and permanent RLN injury have not been clearly defined, they are based on persistent hoarseness or vocal cord palsy lasting less than (transient) or more than (permanent) 6 months. The reported rates of transient RLN injury following BABA RT vary from $0 \sim 12.1 \%$. Permanent RLN injury was observed in $0.2 \%$ of patients in one study, but not in other studies. ${ }^{5-10}$ In addition, rates of transient and permanent RLN injury did not differ significantly in patients undergoing BABA RT and OT. . $^{6-9,11}$

In BABA RT, intraoperative neuromonitoring (IONM) has been used to identify the RLN and to assess vocal cord function. Postoperative transient and permanent vocal cord palsy were not observed by indirect laryngoscopy, with rates of transient RLN palsy being less than 2\%. The Voice Handicap Index-10 questionnaire found that scores 1 and 3 months after surgery were significantly higher than the preoperative score $(0.20 \pm 0.66,3.47 \pm 5.04$, and $1.53 \pm 2.47 ; p<0.001)$, but that these scores decreased over time. The cause of these alterations may be not only injury of external branch of superior laryngeal nerve but also arytenoid trauma. ${ }^{12}$

\section{Hypoparathyroidism}

The definition of hypoparathyroidism also varies among published studies (Table 2). In most studies, this condition was defined based on serum concentrations of parathyroid hormone (PTH) and calcium (Ca), and on hypocalcemic symptoms. In some studies, transient and permanent hypoparathyroidism were classified as abnormalities lasting less than and more than 6 months, respectively. ${ }^{5-7,11}$ In other institution,

Table 1. Summary of published studies reporting recurrent laryngeal nerve (RLN) injury in patients undergoing BABA robotic thyroidectomy (BABA RT)

\begin{tabular}{|c|c|c|c|c|c|c|}
\hline $\begin{array}{l}\text { First author } \\
\text { /year }\end{array}$ & Affiliate & $\begin{array}{c}\text { Sample size } \\
\text { (BABA RT vs. OT) }\end{array}$ & $\begin{array}{l}\text { Definition of transient } \\
\text { RLN injury }\end{array}$ & $\begin{array}{l}\text { Rates of transient } \\
\text { RLN injury (\%) } \\
\text { (BABA RT vs. OT) }\end{array}$ & $\begin{array}{c}\text { Definition of permanent } \\
\text { RLN injury }\end{array}$ & $\begin{array}{l}\text { Rates of permanen } \\
\text { RLN injury (\%) } \\
\text { (BABA RT vs. OT) }\end{array}$ \\
\hline Kim, 2011 (6) & $\begin{array}{l}\text { Sungkyunkwan } \\
\text { University }\end{array}$ & $69: 138$ & $\begin{array}{l}\text { Vocal cord palsy on } \\
\text { laryngoscopy with recovery } \\
\text { within } 6 \text { months }\end{array}$ & $\begin{array}{l}1.4: 0.7 \\
(p=0.62)\end{array}$ & $\begin{array}{l}\text { Failure of voice change to } \\
\text { normalize after } 6 \text { months }\end{array}$ & $\begin{array}{c}0: 0 \\
(p=N S)\end{array}$ \\
\hline Kim, 2012 (10) & Korea University & 93 & Not stated & 3.2 & Not stated & 0 \\
\hline Lee, 2013 (5) & $\begin{array}{l}\text { Seoul National } \\
\text { University }\end{array}$ & 1,026 & $\begin{array}{l}\text { Vocal cord palsy on } \\
\text { laryngoscopy }\end{array}$ & 12.1 & Not stated & 0.2 \\
\hline Kim, 2014 (7) & $\begin{array}{l}\text { Chung-Ang } \\
\text { University }\end{array}$ & $123: 392$ & $\begin{array}{l}\text { Vocal cord palsy persisted } \\
<6 \text { months }\end{array}$ & $\begin{array}{l}4.9: 6.1 \\
(p=0.60)\end{array}$ & $\begin{array}{l}\text { Vocal cord palsy persisted } \\
\quad>6 \text { months }\end{array}$ & $\begin{array}{l}0: 0.3 \\
(p=1.0)\end{array}$ \\
\hline Kwak, 2015 (8) & $\begin{array}{c}\text { Korea } \\
\text { University }\end{array}$ & $206: 634$ & $\begin{array}{l}\text { Vocal cord palsy on } \\
\text { stroboscopy from } \\
2 \text { weeks to } 6 \text { months }\end{array}$ & $\begin{array}{l}0.9: 0.5 \\
(p=0.36)\end{array}$ & & NR \\
\hline Cho, 2016 (11) & $\begin{array}{l}\text { Kyung Hee } \\
\text { University }\end{array}$ & $105: 105$ & $\begin{array}{l}\text { Vocal cord palsy on } \\
\text { laryngoscopy }\end{array}$ & $6.7: 5.7$ & $\begin{array}{l}\text { Vocal cord palsy persisted } \\
>6 \text { months }\end{array}$ & $0.9: 0.9$ \\
\hline *Kim, 2015 (9) & $\begin{array}{l}\text { Chung-Ang } \\
\text { University }\end{array}$ & $13: 65$ & $\begin{array}{l}\text { Vocal cord palsy on } \\
\text { laryngoscopy } \\
\text { lasting for }<6 \text { months }\end{array}$ & $\begin{array}{c}0: 4.6 \\
(p=\mathrm{NS})\end{array}$ & $\begin{array}{l}\text { Vocal cord palsy on } \\
\text { laryngoscopy lasting for } \\
>6 \text { months }\end{array}$ & $\begin{array}{c}0: 3.1 \\
(p=\mathrm{NS})\end{array}$ \\
\hline
\end{tabular}

$\mathrm{RLN}=$ recurrent laryngeal nerve; BABA = bilateral axillo-breast approach; $\mathrm{RT}=$ robotic thyroidectomy; $\mathrm{OT}=$ open thyroidectomy; $\mathrm{NR}=$ not reported; NS $=$ not significant. ${ }^{*}$ Total thyroidectomy with modified radical neck dissection (MRND). 
Table 2. Summary of published studies reporting rates of hypoparathyroidism in patients undergoing BABA robotic thyroidectomy (BABA RT)

\begin{tabular}{|c|c|c|c|c|c|c|}
\hline $\begin{array}{l}\text { First author } \\
\text { /year }\end{array}$ & Affiliate & $\begin{array}{c}\text { Sample size } \\
\text { (BABA RT vs. OT) }\end{array}$ & $\begin{array}{l}\text { Definition of transient } \\
\text { hypoparathyroidism }\end{array}$ & $\begin{array}{l}\text { Rates of transient } \\
\text { hypoparathyroidism (\%) } \\
\text { (BABA RT vs. OT) }\end{array}$ & $\begin{array}{l}\text { Definition of permanent } \\
\text { hypoparathyroidism }\end{array}$ & $\begin{array}{l}\text { Rates of permanent } \\
\text { hypoparathyroidism (\%) } \\
\text { (BABA RT vs. OT) }\end{array}$ \\
\hline Kim, 2011 (6) & $\begin{array}{c}\text { Sungkyunkwan } \\
\text { University }\end{array}$ & $69: 138$ & $\begin{array}{l}\text { Normalization of PTH } \\
\text { within } 6 \text { months }\end{array}$ & $\begin{array}{c}33.3: 27.5 \\
(p=0.58)\end{array}$ & $\begin{array}{c}\text { Failure of normalization of } \\
\text { PTH within } 6 \text { months }\end{array}$ & $\begin{array}{l}1.4: 2.9 \\
(p=N S)\end{array}$ \\
\hline Kim, 2012 (10) & $\begin{array}{c}\text { Korea } \\
\text { University }\end{array}$ & 93 & Not stated & 18.2 & Not stated & 0 \\
\hline Lee, 2013 (5) & $\begin{array}{c}\text { Seoul National } \\
\text { University }\end{array}$ & 1,026 & $\begin{array}{l}\text { Normalization of PTH } \\
\text { within } 6 \text { months }\end{array}$ & 33.2 & Not stated & 1.2 \\
\hline Kim, 2014 (7) & $\begin{array}{l}\text { Chung-Ang } \\
\text { University }\end{array}$ & $123: 392$ & $\begin{array}{l}\text { Low PTH within } \\
6 \text { months }\end{array}$ & $\begin{array}{c}23.4: 22.0 \\
(p=0.16)\end{array}$ & $\begin{array}{l}\text { Low PTH persisted for } \\
\quad>6 \text { months }\end{array}$ & $\begin{array}{c}0: 0 \\
(p=N S)\end{array}$ \\
\hline Kwak, 2015 (8) & $\begin{array}{c}\text { Korea } \\
\text { University }\end{array}$ & $206: 634$ & $\begin{array}{l}\text { Serum ionized Ca } \\
<4.4 \mathrm{mEq} / \mathrm{L} \text { or } \\
\text { PTH }<8 \mathrm{pg} / \mathrm{ml} \\
\text { within } 1 \text { year }\end{array}$ & $\begin{array}{l}15: 14.6 \\
(p=0.29)\end{array}$ & $\begin{array}{c}\text { Serum ionized } \mathrm{Ca}<4.4 \\
\mathrm{mEq} / \mathrm{L} \text { or PTH }<8 \mathrm{pg} / \mathrm{ml} \\
\text { persisted after } 1 \text { year and } \\
\text { need of Ca supplement }\end{array}$ & $\begin{array}{l}0.3: 0.5 \\
(p=0.08)\end{array}$ \\
\hline Cho, 2016 (11) & $\begin{array}{l}\text { Kyung Hee } \\
\text { University }\end{array}$ & $105: 105$ & $\begin{array}{c}\text { Serum PTH }<13 \mathrm{pg} / \mathrm{ml} \\
\text { and symptoms requiring } \\
\text { Ca replacement }\end{array}$ & $34.3: 55.2$ & $\begin{array}{l}\text { Serum PTH }<13 \mathrm{pg} / \mathrm{ml} \\
\text { and requiring Ca } \\
\text { replacement lasted } \\
\text { over } 6 \text { months }\end{array}$ & $1.9: 1.9$ \\
\hline *Kim, 2015 (9) & $\begin{array}{l}\text { Chung-Ang } \\
\text { University }\end{array}$ & $13: 65$ & $\begin{array}{l}\text { Serum ionized Ca } \\
<4.0 \mathrm{mEq} / \mathrm{L} \text { or } \\
\text { symptoms requiring } \\
\text { Ca replacement }\end{array}$ & $\begin{array}{l}0: 15.4 \\
(p=N S)\end{array}$ & Not stated & $\begin{array}{l}0: 1.5 \\
(p=\mathrm{NS})\end{array}$ \\
\hline
\end{tabular}

$\mathrm{BABA}=$ bilateral axillo-breast approach; $\mathrm{RT}=$ robotic thyroidectomy; OT = open thyroidectomy; PTH = parathyroid hormone; $\mathrm{Ca}=$ calcium; NS = not significant. ${ }^{*}$ Total thyroidectomy with modified radical neck dissection (MRND).

transient and permanent hypoparathyroidism were based on low serum Ca and PTH levels and the need for Ca supplementation 1 year after BABA RT. ${ }^{8}$ The rate of permanent hypoparathyroidism in patients who underwent BABA RT was less than 2\%. ${ }^{5-11}$ Moreover, in five studies that compared BABA RT and OT, the incidence of permanent hypoparathyroidism was comparable in the two groups. ${ }^{6-9,11}$

\section{Other complications}

The incidences of complications associated with BABA RT were generally low (Table 3). No patient in any study experienced a major complication, such as tracheal or brachial plexus injury. In the study with the largest patient population, four patients experienced hematoma, but none had postoperative bleeding requiring reoperation. ${ }^{5}$

\section{ONCOLOGIC COMPLETENESS OF ONCOPLASTIC THYROID SURGERY}

\section{Stimulated thyroglobulin level}

In most patients who undergo total thyroidectomy, recurrent or residual disease is detected by measuring serum thyroglobulin (Tg) levels. Stimulated $\mathrm{Tg}(\mathrm{sTg})$ after total thyroidectomy reflects the amount of remnant thyroid tissue and may be used to predict persistent or recurrent disease by measuring thyroid bed 131-I uptake after first radioactive iodine (RAI) ablation. The sTg level is measured prior to RAI treatment after elevating the thyroid-stimulating hormone (TSH) concentration, either by thyroid hormone withdrawal or the injection of recombinant human TSH, and compared with control sTg measured 6 12 months after RAI. Therefore, a low sTg level is a reliable indicator of complete resection of the thyroid. A study in 453 patients who underwent BABA RT found that the 
Table 3. Summary of published studies reporting other complications in patients who underwent BABA robotic thyroidectomy (BABA RT)

\begin{tabular}{|c|c|c|c|c|c|c|c|}
\hline $\begin{array}{l}\text { First author } \\
\text { /year }\end{array}$ & Affiliate & $\begin{array}{c}\text { Sample size } \\
\text { (BABA RT) }\end{array}$ & $\begin{array}{l}\text { Tracheal injury } \\
\text { (n) }\end{array}$ & $\begin{array}{l}\text { Brachial plexus } \\
\text { injury (n) }\end{array}$ & $\begin{array}{l}\text { Hematoma } \\
\text { (n) }\end{array}$ & $\begin{array}{l}\text { Seroma } \\
\text { (n) }\end{array}$ & $\begin{array}{l}\text { Chyle leakage } \\
\text { (n) }\end{array}$ \\
\hline Kim, 2011 (6) & $\begin{array}{l}\text { Sungkyunkwan } \\
\text { University }\end{array}$ & 69 & NA & NA & NA & 1 & 1 \\
\hline Kim, 2012 (10) & $\begin{array}{l}\text { Korea } \\
\text { University }\end{array}$ & 93 & NA & NA & 0 & 0 & NA \\
\hline Lee, 2013 (5) & $\begin{array}{l}\text { Seoul National } \\
\text { University }\end{array}$ & 1,026 & NA & NA & 4 & NA & NA \\
\hline Kim, 2014 (7) & $\begin{array}{l}\text { Chung-Ang } \\
\text { University }\end{array}$ & 123 & NA & NA & 0 & NA & NA \\
\hline Kwak, 2015 (8) & $\begin{array}{l}\text { Korea } \\
\text { University }\end{array}$ & 206 & NA & NA & 0 & 1 & NA \\
\hline Cho, 2016 (11) & $\begin{array}{l}\text { Kyung Hee } \\
\text { University }\end{array}$ & 105 & NA & NA & 0 & 0 & 0 \\
\hline *Kim, 2015 (9) & $\begin{array}{l}\text { Chung-Ang } \\
\text { University }\end{array}$ & 13 & NA & NA & 0 & NA & 1 \\
\hline
\end{tabular}

BABA = bilateral axillo-breast approach; RT = robotic thyroidectomy; NA = not available. ${ }^{*}$ Total thyroidectomy with modified radical neck dissection (MRND).

median sTg level at the first RAI ablation was $0.4 \mathrm{ng} / \mathrm{ml}$ (range, $0.1 \sim 79.84 \mathrm{ng} / \mathrm{ml}$ ), with 295 of these patients (65.1\%) having sTg levels $<1.0 \mathrm{ng} / \mathrm{ml}$ (Table 4). ${ }^{5}$ Other studies found that sTg levels at the first RAI treatment were similar in patients who underwent BABA RT and OT, ${ }^{3,6,7,11}$ sTg levels at diagnostic whole body scan after RAI ablation were also similar in patients who underwent BABA RT and OT $(1.01 \pm 2.16$ vs. $1.17 \pm 3.73$, $p=0.778),{ }^{13,14}$ as was RAI uptake rate at the first whole body scan $(11.1 \% \text { vs. } 5.9 \%, p=0.564)^{14-17}$

\section{POSTOPERATIVE QUALITY OF LIFE AFTER ONCOPLASTIC THYROID SURGERY}

\section{Cosmesis}

Scarring of the face and neck scar after thyroidectomy is associated with patient quality of life. The cosmetic superiority of absence of neck scaring is the major factor for patients to choose RT. ${ }^{18}$ A prospective questionnaire study addressing surgical scarring and physical and psychological distress in 129 patients who underwent thyroidectomy found that the degrees of surgical scarring and psychological distress were lower in the 51 patients who underwent BABA RT than in the 78 who underwent OT. The level of physical distress, including pain and exercise limitation, however, did not differ in these two groups. ${ }^{19}$

\section{Postoperative pain}

Because BABA ET and RT require a larger flap than OT, concerns have been raised regarding postoperative neck and chest pain in the former. However, one study reported a similar degree of postoperative pain, as measured by a visual analogue scale, after BABA RT and OT in 27 patients each. ${ }^{20}$ In that study, pain scores were compartmentalized for the throat, anterior neck, left and right chest, posterior neck, and back and were recorded on postoperative days 1, 2, 3, and 14. Postoperative analgesic requirements and postoperative pain in the four compartments were similar in the two groups. Another study reported that postoperative pain score at operation day and postoperative 1day was no significant differences between patients who underwent BABA RT or OT (3.84 \pm 1.11 vs. $3.76 \pm$ 1.22, $p=0.069){ }^{11}$

\section{Sensory changes}

BABA RT requires more extensive skin flap dissection than OT, including in the neck subplatysmal area, anterior chest subcutaneous area, and subcutaneous tissue tunneling in the bilateral breast and axillae. Thus, there is concern about potential sensory changes of the skin flap, especially of the anterior chest area. Although a prospective study found that sensory changes in the anterior chest area occurred 1 month after BABA RT, these changes were normalized by 3 months. ${ }^{21}$ 
Table 4. Studies reporting rates of surgical completeness in patients undergoing BABA robotic thyroidectomy (BABA RT)

\begin{tabular}{|c|c|c|c|}
\hline $\begin{array}{l}\text { First author } \\
\text { /year }\end{array}$ & Affiliate & $\begin{array}{c}\text { Sample size } \\
\text { (BABA RT vs. OT) }\end{array}$ & $\begin{array}{l}\text { Mean ablation sTg (ng/ml) } \\
\text { (BABA RT vs. OT) }\end{array}$ \\
\hline Kim, 2011 (6) & $\begin{array}{c}\text { Sungkyunkwan } \\
\text { University }\end{array}$ & $69: 138$ & $\begin{array}{l}0.8: 0.8 \\
(p=0.97)\end{array}$ \\
\hline Lee, 2011 (3) & $\begin{array}{c}\text { Seoul National } \\
\text { University }\end{array}$ & $174: 237$ & $\begin{array}{l}1.4: 1.2 \\
(p=0.99)\end{array}$ \\
\hline Lee, 2013 (5) & $\begin{array}{l}\text { Seoul National } \\
\text { University }\end{array}$ & 1,026 & 0.4 \\
\hline Kim, 2014 (7) & $\begin{array}{l}\text { Chung-Ang } \\
\text { University }\end{array}$ & $123: 392$ & $\begin{array}{l}1.3: 1.1 \\
(p=0.65)\end{array}$ \\
\hline Kwak, 2015 (8) & $\begin{array}{l}\text { Korea } \\
\text { University }\end{array}$ & 206 : 634 & NR \\
\hline Cho, 2016 (11) & $\begin{array}{l}\text { Kyung Hee } \\
\text { University }\end{array}$ & $105: 105$ & $\begin{array}{l}0.2: 0.25 \\
(p=0.954)\end{array}$ \\
\hline *Kim, 2015 (9) & $\begin{array}{l}\text { Chung-Ang } \\
\text { University }\end{array}$ & $13: 65$ & $\begin{array}{l}2.5: 2.8 \\
(p=N S)\end{array}$ \\
\hline
\end{tabular}

$\mathrm{BABA}=$ bilateral axillo-breast approach; $\mathrm{RT}=$ robotic thyroidectomy; OT = open thyroidectomy; sTg = thyrotropin-stimulated serum thyroglobulin; NR = not reported. NS $=$ not significant. ${ }^{*}$ Total thyroidectomy with modified radical neck dissection.

Therefore, sensory changes after surgery were considered transitory.

\section{Breast imaging}

Because BABA RT requires subcutaneous tunneling in the bilateral breast for flap dissection, concerns have been raised that this procedure might interfere with subsequent breast imaging. Unpublished data from our institute found that breast imaging, by mammography or ultrasonography, identified 180 breast nodules in 108 patients who underwent BABA RT, with postoperative structural or fibrotic changes having no effect.

\section{EXPANSION OF APPLICATIONS OF ONCOPLASTIC THYROID SURGERY}

\section{Saving of the external branch of the superior laryngeal nerve}

The external branch of the superior laryngeal nerve (EBSLN) innervates the cricothyroid muscle and acts on the thyroarytenoid muscle to increase tension of the ipsilateral vocal fold, indicating that the function of this nerve is especially associated with an increase in pitch. ${ }^{22,23}$ A study of patients who underwent BABA RT combined with ligation of the superior thyroid poles after intraoperative monitoring confirmed the location of the EBSLN found that the phonation-efficient in- dex was significantly lower 1 month after surgery than before treatment. ${ }^{24}$ EBSLN were identified in $73 \%$ through neuromonitoring. Laryngeal EMG results showed 4 cases of neuropathy among 19 nerves at 1 month postoperatively, but they were completely recovered after 3 months. ${ }^{24}$ Intraoperative monitoring of the RLN and EBSLN during BABA RT was feasible and may be helpful in preserving patients' voices.

\section{Graves' disease}

Graves' disease is considered a relative contraindication for ET because of the narrow operative view, increased vascularity, a large-sized thyroid gland, and difficulties controlling bleeding. Recent technical advances and accumulated experience with BABA RT have enabled its use in patients with Graves' disease, although conventional OT is still considered one of the safest and most effective approaches. BABA RT was successfully performed in 30 patients with Graves' disease, with none experiencing major complications, such as postoperative bleeding, conversion to open surgery, or permanent RLN injury. ${ }^{25}$ Another study in patients with Graves' disease compared BABA RT in 44 patients with OT in 145 , finding that none of these experienced recurrence of Graves' disease after a median follow-up of 35 months. Complication rates, including permanent RLN palsy ( $0 \%$ vs. $2.3 \% ; p=0.315$ ) and permanent hypoparathyroidism (2.3\% vs. $2.3 \% ; p=1.000$ ), were comparable in the BABA RT and OT groups after pro- 
pensity score matching. These findings suggest that BABA RT may be feasible and safe for patients with Graves' disease who are concerned about cosmesis. ${ }^{26}$

\section{Thyroid carcinoma larger than $2 \mathrm{~cm}$}

The application of BABA RT has gradually expanded beyond small-sized thyroid carcinomas to relatively large-sized thyroid carcinomas. ${ }^{27}$ A comparison in patients with $2 \sim 4 \mathrm{~cm}^{-}$ sized thyroid carcinomas found no significant differences between the BABA RT $(n=21)$ and OT $(n=65)$ groups in rates of vocal cord palsy (transient, $19.0 \%$ vs. 9.2\%; permanent, $0 \%$ vs. $1.5 \%$ ) and postoperative hypoparathyroidism (transient, $19.0 \%$ vs. $33.8 \%$; permanent, $4.8 \%$ vs. $1.5 \%$ ). At the time of initial RAI treatment, $64.7 \%$ (11/17) of patients in the BABA RT group and 66.0\% (35/53) in the OT group had serum sTg levels $<1.0 \mathrm{ng} / \mathrm{ml}(p=0.920)$. In addition, none of these patients experienced anatomical recurrence or died during a median follow-up of 40.2 months.

\section{BABA robotic MRND}

Although MRND is standard treatment in patients with lateral cervical metastasis, the procedure leaves an extensive transverse cervical scar on the skin in the neck area. Robotic MRND using BABA may be a good alternative to avoid an extensive incision scar. BABA robotic MRND was found to be as safe and show similar postoperative oncologic outcomes as OT. ${ }^{9}$ A similar number of lateral lymph nodes was retrieved following BABA robotic and open MRND, without postoperative bleeding (Horner's syndrome). Chyle leakage was lower with robotic BABA than with MRND. Our unpublished data in 15 patients also showed that BABA robotic MRND was safe, with none experiencing permanent RLN injury or hypocalcemia. Horner's syndrome occurred in one patient, but this patient showed symptom improvement 6 months after surgery without further treatment. The median sTg concentration level was $0.8 \mathrm{ng} / \mathrm{ml}$ at the first RAI treatment, with $53.3 \%$ and $90 \%$ of these patients having sTg levels $<1 \mathrm{ng} / \mathrm{ml}$ and $<2 \mathrm{ng} / \mathrm{ml}$, respectively. The operation time was longer in the robotic group than in the open group (210 min vs $382 \mathrm{~min}, p<0.001$ ).

\section{BABA Sistrunk operation}

The standard surgical approach to thyroglossal duct cyst (TGDC) is a Sistrunk operation. ${ }^{28}$ Complications and recurrence rates are rare in this procedure, ${ }^{29}$ but it leaves a scar on the neck. Sistrunk operation using BABA in two patients with TGDC resulted in a total blood loss of 100 and $80 \mathrm{ml}$, respectively. ${ }^{30}$ TGDC was completely removed along the TGDC tract, including partial resection of the hyoid bone. Both patients were discharged on postoperative day 3 without complications.

\section{CONCLUSIONS}

Oncoplastic thyroid surgery using BABA offers constructive surgical safety, excellent oncologic outcomes, and good quality of life, including excellent cosmetic results. In addition, BABA RT has expanded beyond patients with benign thyroid nodules and small-sized papillary thyroid carcinomas (PTCs) to include patients with Graves' disease, relatively large-sized PTCs, PTCs with lateral neck metastasis, and TGDC. Oncoplastic thyroid surgery is therefore a good alternative surgical method for patients who desire surgical safety, oncological completeness, and better cosmetic outcomes.

\section{ACKNOWLEDGMENTS}

This research was supported by the Basic Science Research Program through the National Research Foundation of Korea (NRF), funded by the Ministry of Science, ICT \& Future Planning, Republic of Korea (grant number: 2015R1C1A1A01055464).

\section{REFERENCES}

1) Xing M. BRAF mutation in thyroid cancer. Endocr Relat Cancer 2005; 12:245-262.

2) Kang SW, Jeong JJ, Nam KH, Chang HS, Chung WY, Park CS. Robot-assisted endoscopic thyroidectomy for thyroid malignancies using a gasless transaxillary approach. J Am Coll Surg 2009;209:e1-7.

3) Lee KE, Choi JY, Youn YK. Bilateral axillo-breast approach robotic thyroidectomy. Surg Laparosc Endosc Percutan Tech 2011;21:230-236.

4) Inabnet WB, 3rd. Robotic thyroidectomy: must we drive a luxury sedan to arrive at our destination safely? Thyroid 2012;22:988990.

5) Lee KE, Kim E, Koo do H, Choi JY, Kim KH, Youn YK. Robotic thyroidectomy by bilateral axillo-breast approach: review of 1,026 cases and surgical completeness. Surg Endosc 2013;27:2955-2962.

6) Kim WW, Kim JS, Hur SM, et al. Is robotic surgery superior to endoscopic and open surgeries in thyroid cancer? World J Surg 2011;35:779-784.

7) Kim BS, Kang KH, Kang H, Park SJ. Central neck dissection using a bilateral axillo-breast approach for robotic thyroidectomy: comparison with conventional open procedure after propensity score matching. Surg Laparosc Endosc Percutan Tech 2014;24:6772.

8) Kwak HY, Kim HY, Lee HY, et al. Robotic thyroidectomy us- 
ing bilateral axillo-breast approach: Comparison of surgical results with open conventional thyroidectomy. J Surg Oncol 2015;111:141-145.

9) Kim BS, Kang KH, Park SJ. Robotic modified radical neck dissection by bilateral axillary breast approach for papillary thyroid carcinoma with lateral neck metastasis. Head Neck 2015;37:37-45.

10) Kim HY, d’Ajello F, Woo SU, Son GS, Lee JB, Bae JW. Robotic thyroid surgery using bilateral axillo-breast approach: personal initial experience over two years. Minerva Chir 2012;67:39-48.

11) Cho JN, Park WS, Min SY, Han SA, Song JY. Surgical outcomes of robotic thyroidectomy vs. conventional open thyroidectomy for papillary thyroid carcinoma. World J Surg Oncol 2016;14:181.

12) Bae DS, Kim SJ. Intraoperative neuromonitoring of the recurrent laryngeal nerve in robotic thyroid surgery. Surg Laparosc Endosc Percutan Tech 2015;25:23-26.

13) Yi O, Yoon JH, Lee YM, et al. Technical and oncologic safety of robotic thyroid surgery. Ann Surg Oncol 2013;20:1927-1933.

14) Tae K, Song CM, Ji YB, Kim KR, Kim JY, Choi YY. Comparison of surgical completeness between robotic total thyroidectomy versus open thyroidectomy. Laryngoscope 2014;124:1042-1047.

15) Lee S, Ryu HR, Park JH, et al. Early surgical outcomes comparison between robotic and conventional open thyroid surgery for papillary thyroid microcarcinoma. Surgery 2012;151:724-730.

16) Kang SW, Lee SH, Park JH, et al. A comparative study of the surgical outcomes of robotic and conventional open modified radical neck dissection for papillary thyroid carcinoma with lateral neck node metastasis. Surg Endosc 2012;26:3251-3257.

17) Lee S, Kim HY, Lee CR, et al. A prospective comparison of patient body image after robotic thyroidectomy and conventional open thyroidectomy in patients with papillary thyroid carcinoma. Surgery 2014;156:117-125.

18) Choi Y, Lee JH, Kim YH, et al. Impact of postthyroidectomy scar on the quality of life of thyroid cancer patients. Ann Dermatol 2014:26:693-699.

19) Koo DH, Kim DM, Choi JY, Lee KE, Cho SH, Youn YK. InDepth Survey of Scarring and Distress in Patients Undergoing Bilateral Axillo-Breast Approach Robotic Thyroidectomy or Conventional Open Thyroidectomy. Surg Laparosc Endosc Percutan
Tech 2015;25:436-439.

20) Chai YJ, Song J, Kang J, et al. A comparative study of postoperative pain for open thyroidectomy versus bilateral axillo-breast approach robotic thyroidectomy using a self-reporting application for iPad. Ann Surg Treat Res 2016;90:239-245.

21) Kim SJ, Lee KE, Myong JP, Koo do H, Lee J, Youn YK. Prospective study of sensation in anterior chest areas before and after a bilateral axillo-breast approach for endoscopic/robotic thyroid surgery. World J Surg 2013;37:1147-1153.

22) Cernea CR, Ferraz AR, Furlani J, et al. Identification of the external branch of the superior laryngeal nerve during thyroidectomy. Am J Surg 1992;164:634-639.

23) Friedman M, LoSavio P, Ibrahim H. Superior laryngeal nerve identification and preservation in thyroidectomy. Arch Otolaryngol Head Neck Surg 2002;128:296-303.

24) Kim SJ, Lee KE, Oh BM, et al. Intraoperative neuromonitoring of the external branch of the superior laryngeal nerve during robotic thyroid surgery: a preliminary prospective study. Ann Surg Treat Res 2015;89:233-239.

25) Kwon H, Koo do H, Choi JY, Kim E, Lee KE, Youn YK. Bilateral axillo-breast approach robotic thyroidectomy for Graves' disease: an initial experience in a single institute. World J Surg 2013;37:1576-1581.

26) Kwon H, Yi JW, Song RY, et al. Comparison of Bilateral AxilloBreast Approach Robotic Thyroidectomy with Open Thyroidectomy for Graves' Disease. World J Surg 2016;40:498-504.

27) Chai YJ, Suh H, Woo JW, et al. Surgical safety and oncological completeness of robotic thyroidectomy for thyroid carcinoma larger than $2 \mathrm{~cm}$. Surg Endosc 2017;31:1235-1240.

28) Sistrunk WE. The surgical treatment of cysts of the thyroglossal tract. Ann Surg 1920;71:121-122.2.

29) Maddalozzo J, Venkatesan TK, Gupta P. Complications associated with the Sistrunk procedure. Laryngoscope 2001;111:119-123.

30) Paek SH, Choi JY, Lee KE, Youn YK. Bilateral axillo-breast approach (BABA) endoscopic Sistrunk operation in patients with thyroglossal duct cyst: technical report of the novel endoscopic Sistrunk operation. Surg Laparosc Endosc Percutan Tech 2014;24:e95-98. 